\title{
Performing right: legal constraints and Beckett's plays on BBC television
}

Article

Accepted Version

Bignell, J. (2015) Performing right: legal constraints and Beckett's plays on BBC television. Samuel Beckett Today / Aujourd'hui, 27. 129- 142. ISSN 0927-3131 doi: https://doi.org/10.1163/9789004309937_011 Available at https://centaur.reading.ac.uk/40381/

It is advisable to refer to the publisher's version if you intend to cite from the work. See Guidance on citing.

To link to this article DOI: http://dx.doi.org/10.1163/9789004309937_011

Publisher: Brill/ Rodopi

All outputs in CentAUR are protected by Intellectual Property Rights law, including copyright law. Copyright and IPR is retained by the creators or other copyright holders. Terms and conditions for use of this material are defined in the End User Agreement.

\section{www.reading.ac.uk/centaur}

\section{CentAUR}

Central Archive at the University of Reading

Reading's research outputs online 


\title{
PERFORMING RIGHT(S): Legal Constraints and Beckett's Plays on BBC Television
}

\author{
Jonathan Bignell
}

Drawing on BBC archival documentation, this article outlines how BBC television versions of Beckett's plays were affected by copyright. Rights to record and broadcast original drama for the screen differ from those governing adaptations of existing theatre plays. Rights can be assigned for specific territories and periods of time, and are negotiated and traded via complex contractual agreements. Examining how Beckett's agents and the BBC dealt with rights sheds new light on the history of his work on television.

My work on Beckett has increasingly focused on materialist analyses of his original dramas for television and television adaptations of his theatre plays (Bignell 2009, 2010), asking how these plays came to be made, by whom, and in what ways. For me, the study of Beckett's screen work is not only an important aspect of Beckett studies but also a facet of media history and specifically the historiography of television drama. The argument of this article is that the existence of screen versions of Beckett's drama has been dependent on legal and commercial processes similar to those governing other dramatic broadcasting, and that a proper understanding of his media work needs to include an account of those processes. This article aims to document how Beckett's work was assimilated into the conventions of the media industry and the legal frameworks that govern its operations. Beckett's work on television was enabled and also constrained by those conventions and laws, becoming a form of property that was in many ways outside his authorial control. The particular focus in this article is copyright, especially performing rights and cinematographic rights, since these are the kinds of rights most significant to screen drama (Cotterell). The BBC in Britain has preserved meticulous records of the processes by which Beckett's original and adapted television drama came to be made, which make it possible to undertake this archival study. The BBC Written Archives Centre in Caversham, near Reading 
in England, holds all of the written records of BBC programme making since the beginning of British broadcasting in 1922, and all of the factual information in this article derives from analysis of original documents held there. ${ }^{1}$

Copyright is a legal right over property, and it gives an author the exclusive right to publish, reproduce, perform, broadcast or adapt an original literary, dramatic or other artistic work. So Beckett himself and the agents representing him had the legal authority to use his work in various ways. But of course in the case of a television play or a theatre play, Beckett would grant the right to perform and broadcast a play to an institution such as the Royal Court Theatre or the BBC, in exchange for a fee. There are thus two aspects of copyright that I focus on here. One is performing rights, which grant the right to present a script in the form of a performance by actors. The second aspect that concerns me is cinematographic rights, which are the rights to make a recording (on film or videotape, for example) so that it can be shown to an audience at a subsequent time by means of film projection or broadcasting. All of Beckett's television work shown by the BBC was recorded, rather than live, so it was covered by cinematographic rights.

Both performance rights and cinematographic rights are forms of subsidiary rights, a category that also includes merchandising and commercial exploitation, and the intention of the law is to enable the creator of a work to benefit from uses of the work by the author or by a person or organization acting on the author's behalf. Assigning rights is done by means of a contract that is enforceable in the courts, and once rights are assigned by the author, they are the assignee's property and no longer under the author's control. Copyright respects and protects creative endeavor, but also reifies it so that it can be bought and sold in a relatively free market.

When Beckett's drama was being televised in the 1960s and 1970s the $\mathrm{BBC}$, like any other television institution, had well developed practices and procedures for obtaining copyright when its staff wanted to commission original dramatic work or to adapt existing theatre plays. Producers were on the look-out for interesting and suitable plays and playwrights. They discussed commissions with authors and called on the services of the legal specialists in their Copyright Department to draw up contracts. The details of the commission were worked out with the author's agent, acting as a professional intermediary with a remit to gain the most advantageous terms for the author. Beckett always benefitted from being in the BBC's 'experienced writer' category, 
which meant he was paid better for his work than a dramatist with little track record, but his agents continually argued (with some success) that he deserved yet more money because of his standing. In general, the agent's role was to get the highest possible fee, and also to limit the kinds of rights that were to be assigned to the BBC. Such limitations might include assigning rights only for a specified period of time, or for exploitation of the television programme within only a certain geographical area. This Of course, assigning limited rights of course left open the prospect of making simultaneous deals with other institutions for the remaining, unassigned, rights that had not yet been assigned. The detail of how these processes worked (and often failed to work effectively) is fascinating in regard to Beckett's drama.

\section{Eh Joe: Televising an Original Script}

Although the BBC had televised versions of Beckett's theatre work prior to 1966, as I discuss below, it may be helpful to give an account of the impact of copyright on commissioning this original drama before delving into the complexities of adapting an existing play. Margaret McLaren, who worked for Beckett's London agent Curtis Brown, sent Beckett's new play for television Eh Joe to Michael Bakewell, drama producer at the BBC. The Drama Department wanted to put it into production, so on 17 June 1965 James Brabazon of the Drama staff sent a standard enquiry form to the BBC Copyright Department declaring the wish to buy the play (T48/74/1). On 28 June, Edward Caffrey of BBC Copyright Department wrote to Margaret McLaren, offering $£ 125$ for rights to make a broadcast of the play. On 1 July 1965, McLaren wrote back (RCONT 18), refusing even to suggest the sum of $£ 125$ to Beckett for Eh Joe because it seemed derisory, noting that she was free to sell the play to anyone she wished (in other words, to the BBC's commercial rival ITV) and asking for a fee of $£ 600$. On 5 July 1965, a year before the play was screened, the BBC agreed a compromise fee of $£ 250$ and on 23 July the contract was drawn up (RCONT 18).

The contract governing Eh Joe assigned various rights to the BBC. They had a two-year exclusive opportunity to broadcast the play, after the date the script was delivered. If the play had not been televised by that time, all of the broadcast rights reverted to Beckett and could be sold to someone else. The play could be performed only once, but could be recorded and repeated in the UK any number of times in the year following first transmission. The contract gave the BBC exclusive rights over a five-year period to license the recording of Eh Joe to 
broadcasters around the world so they could screen it in their own country, in all territories except Western Europe. Different levels of fee were due to Beckett if the play was shown in different countries; for example, Beckett would get another $£ 250$ fee from a sale of Eh Joe to a TV channel in the USA, but only 25 per cent of his original fee if there were an Australian sale, and only 10 per cent if there were a sale to a broadcaster in Latin America. In such circumstances, the rest of the income from the licence to broadcast overseas would be retained by the BBC. Some standard clauses in the contract were deleted. Clearly Curtis Brown thought there was scope for separate agreements with European television stations to make their own versions of Eh Joe (and of course this proved to be the case), so clauses granting Beckett another 150 per cent of his fee if there were sales to Germany, 25 per cent to Italy and 10 per cent for elsewhere in Europe were crossedthrough. Other standard clauses were retained; the BBC had the right to record rehearsals for training its in-house directors and technical staff, for making promotional trailers advertising the broadcast of Eh Joe, and the right to dub or subtitle the play. In the light of Beckett's wellknown resistance to modifications of his text, it is very surprising that the latter clause was not deleted. Probably no-one spotted the issue. Finally, to safeguard the investment the BBC would make in producing Eh Joe, the contract specified that Beckett would not license or sell the play for television anywhere else for one year following the first BBC screening.

What we see here is that Beckett's play becomes a piece of property over which the $\mathrm{BBC}$ gains exclusive rights. Copyright allows the author to assign rights to someone else, and they are divisible by geographical territory and medium, and can be licensed, sub-licensed or assigned for a specified period of time. But signing the contract removes the work from Beckett's authorial control, and subsequently, not for the first time, Beckett's personal involvement and the complexity of his growing international reputation caused some severe headaches for his legal representatives.

On 31 August 1965, Margaret McLaren of the agents Curtis Brown wrote very apologetically to Edward Caffrey of the BBC Copyright Department (RCONT 18). She reported that, having already signed the contract with the BBC, Beckett had told her he had sent a copy of his Eh Joe script to the director Alan Schneider and it was a shame that the BBC had acquired exclusive rights to the play in the USA. McLaren was now in the embarrassing position of having to ask 
the BBC to waive its US television rights if Schneider managed to set up a TV production of Eh Joe there. She explained that such conflicts might easily arise when dealing with Beckett, because as an internationally famous writer the remit of various agents, publishers and theatre managements around the world might easily overlap or conflict. Not least, we might now add, it was very hard to maintain accurate information in an age before networked electronic databases such as the ones that broadcasting institutions now use to track rights and transactions. McLaren had a further question, which was whether the BBC would allow Süddeutscher Rundfunk (SDR) in Germany to make a television version in April 1966. This would conflict with the BBC's exclusive rights.

The answer from Richard Walford, the Head of the BBC Copyright Department, to McLaren on 8 September 1965 (RCONT 18) revealed a pragmatic attitude towards both Schneider and SDR. Walford dropped the Schneider problem back into McLaren's lap, asking that she sort out the situation before the overseas sales arm, BBC Enterprises, got started on its effort to sell a licence to broadcast the videotaped Eh Joe in the USA. Fortunately, as it turned out, by the time Eh Joe was broadcast by BBC in July 1966, Schneider's US version of the play had fallen through. Walford also agreed to SDR broadcasting Eh Joe before the BBC's exclusive rights to the play expired. Later, the BBC agreed to a request of 14 January 1966 (RCONT 18) sent via Curtis Brown from Bjørn Lense-Møller of TV-Teaterafdelingen (the TV drama department) at Danmarks Radio (DR), to allow DR to make an Eh Joe in March 1966 for television broadcast in Denmark in the autumn of that year. Potentially, the BBC's exclusive control over $E h$ Joe was being eroded, but it seems that the BBC's prime position as broadcaster of Beckett's drama permitted a degree of generosity. Probably the $\mathrm{BBC}$ was also relatively accommodating to fellow public broadcasting corporations like DR and SDR, in a way that it might not be to a private, commercial channel.

Later, on 17 December 1968 (RCONT 18), Judith Leonard at Curtis Brown wrote to the BBC Copyright Department to forward a request by the German broadcaster ARD (in fact by Degeto Film, a subsidiary of ARD) to screen the BBC's Eh Joe in English. When Walford, Head of Copyright, replied on 1 January 1969 (RCONT 18), he advised that Curtis Brown should negotiate direct with Degeto and agree a price for Beckett's rights in the script of Eh Joe (since by this time the $\mathrm{BBC}$ no longer had exclusive rights to it). Subsequently the 
BBC would sell a licence to Degeto that allowed Degeto to screen the BBC Eh Joe in Germany. This situation is rather complex, but, in short, the important distinction is between Beckett's rights as the author of the original script, and the BBC's right to sell its recording of the play: these are two separate (though connected) negotiations.

There are three main points to make about the story of Eh Joe's rights. First, televising a Beckett script was a complex process that took about a year between starting planning and the programme reaching the screen, and involved negotiations between Beckett, his agents, BBC producers, $\mathrm{BBC}$ specialist copyright advisors, and subsequently third parties in various overseas countries. Second, the value of Beckett's intellectual property was recognized right from the start of this process, and negotiations over fees and sales income were lively and ongoing throughout it. Third, Beckett was sometimes keen to make agreements with friends that conflicted with the legally binding contracts he had already signed, or that his agents had signed for him, and this meant that pragmatism and goodwill were often needed from all parties. Things were even more uncertain when theatre plays were considered for broadcast adaptation.

\section{Theatre Plays: Waiting for Godot and Not I}

Television producers at the BBC were well aware of Beckett's work in the theatre, and staff at the Drama Department, headed by Michael Barry, made moves to commission television adaptations at least as early as 1960. A key part of this, of course, was to get the author to agree that his or her theatre play could be adapted for the television medium. Robin Wade, Script Organiser for TV, inquired about the rights to Waiting for Godot on 17 May 1960 by sending a standard proforma called an Existing Material Brief to the BBC's Head of Copyright (T48/74/1). This simple printed memo acted as a request for the BBC's rights team to find out from an author's agent whether rights were available for a television version of a novel, stage play or short story, for example. Peter Hall's stage version of Waiting for Godot had premiered at the Arts Theatre in London in 1955, and the BBC's aim, outlined by Barry in a memo to the Controller of Programmes on 23 August 1960 (T48/74/1) was to include it in a possible series of controversial recent dramas (called Club Theatre in 1960, though the series title was later dropped).

The series was to feature work by Doris Lessing, Harold Pinter, M. F. Simpson and Arnold Wesker. Beckett, via his agent Curtis Brown 
in the person of Margaret McLaren, was dissatisfied with the proposed $£ 200 \mathrm{fee}$, and would not agree to cutting the play to 60 minutes. He stipulated that his friend and collaborator Donald McWhinnie should direct, which the BBC's Head of Copyright suggested should be pursued as long as BBC radio would release McWhinnie from his duties at the appropriate time. McWhinnie was under contract to BBC radio, so one contract would potentially conflict with the other. Barry's memo to the Controller of Programmes urged swift action to sweeten the deal enough to make it happen, because one of Britain's commercial television companies, making drama for the BBC's competitor channel ITV, was apparently courting Beckett with a similar offer. $^{2}$ On 11 April 1961, Walford, Head of Copyright, wrote to McLaren at Curtis Brown to confirm a phone conversation they had just had, in which Walford agreed to raise Beckett's fee for Waiting for Godot to $£ 250$. On their part, Curtis Brown would have accepted $£ 200$ but Beckett himself was not happy and Walford jotted a handwritten note on his memo, stating his view that another $£ 50$ would be worth it to keep Beckett on-side. Waiting for Godot was taped on 15 June 1961 and transmitted on 4 July.

There is a second kind of permission needed for a television version of an existing play, namely the rights to screen it if the television version is to be aired around the same time as a theatre production. Theatre producers and venues have always been concerned that a television adaptation of a play could erode the potential audience willing to buy tickets to see a live production, and thus reduce their income. The performing rights in a dramatic work (known as Grand Rights) are often divided into amateur or Second Class rights, and First Class Rights, which latter means the right to present live stage performances of a work in venues of significant size, location and reputation, with professional performers and creative team. Productions in London theatres in the West End, the major publicly subsidized theatres or in large metropolitan venues would be governed by First Class Rights, whereas student productions or productions by amateur dramatic societies would come within Second Class Rights. Plans for BBC versions of Beckett's plays were affected by 'hold-back,' in which broadcast rights were reserved for a period because theatre companies had been previously granted exclusive First Class performing rights.

Exclusive performing rights had not been a problem for the 1961 $\mathrm{BBC}$ version of Godot, but caused a lot of difficulty (unnecessarily, it turned out) in 1975. The Open University (OU) and BBC wanted to 
collaborate on a television adaptation of act 2 of Godot in 1975, to be screened as an educational broadcast on the BBC2 channel. Richard Callanan of the OU's Arts Faculty had an office at the BBC's Alexandra Palace studios and wrote an internal memo to the BBC Copyright Department on 13 August 1975 (RCONT 20), asking about rights to Godot among other modern plays that he wanted to record for the OU's television broadcasts. The OU catered mainly for mature students, studying part-time, and produced not only conventional printed course materials and books for its courses but also television programmes. It had a highly respected Drama degree course, and provided production funding to the $\mathrm{BBC}$ that was used for making extracts from a range of plays so that OU students (and any other viewer too) could see them performed via television. However, the Royal Court Theatre in London held First Class rights for a theatre production of Godot, and Warren Brown, Beckett's agent at the Spokesmen agency, wrote to Ben Travers of the BBC Copyright Department on 27 August 1975 (RCONT 20) to say that the Royal Court was denying all performing rights for Godot until after their Beckett season in Spring 1976.

Two days later, Antony Jennings, the BBC's Head of Copyright, tried to argue that the academic version for the Open University broadcast was not competing for the same audience as the Royal Court's performances, and so should be allowed to go ahead, but Warren Brown reiterated the Royal Court's position. Callanan managed to deal with this impasse by phoning Nicholas Wright, artistic director at the Royal Court, to promise that the television version of Godot would not be aired until August 1977. Since that was after the end of the Royal Court's Beckett season, they agreed to the OU/BBC version. Callanan wrote to the BBC Copyright Department asking them to write to Anne Jenkins, General Manager of the Royal Court, so that she could confirm to Beckett's agent Warren Brown that he could allow the BBC to film Godot for the OU, and the final stumbling-block was removed when on 13 October Brown wrote to Travers confirming that Beckett would, unusually, allow only an extract from the play to be performed. After all of this back-and-forth, which originally arose from a misunderstanding about how long it would take for the television Godot to reach the screen, a contract was finally drawn up on 17 October 1975 and the drama was produced.

The Royal Court Theatre also had exclusive performance rights to Not I throughout the calendar year of 1973. Naomi Capon, the producer 
of the BBC's arts programme Full House notified the BBC Copyright Department on 14 February 1973 (RCONT 20) that she wanted to film the theatre production. Negotiations continued through March and April because the BBC needed the agreement of Oscar Lowenstein, the Royal Court's artistic director, to filming the theatre production for a BBC broadcast. Furthermore, Grove Press held the US performing rights to Not $I$ and were conducting negotiations to make their own television version, so any BBC production could only be screened in the UK. Fortunately, the Royal Court was willing for the BBC to film a performance of Not I, as letters between Curtis Brown and the BBC Copyright Department in May 1973 show (RCONT 20), despite the fact that the hold-back over performing rights to the play meant that it could not be screened on television until months later.

As in the case of Eh Joe, Beckett himself added a further twist to the story when he gave Billie Whitelaw a veto over plans for the filming of her performance. She was not willing to take part until October 1973, but eventually the recording went ahead at the BBC's film studios. Full House was an experimental arts magazine programme, of two hours duration, which included live performance, poetry, comedy and interviews with artists and writers. It was controversial and received critical condemnation from the conservative press and ambivalent support within the BBC, so it was cancelled in 1973. As a result the acclaimed BBC film of Whitelaw's performance was transmitted in a quite different and more sober context, accompanied by Ghost Trio, ...but the clouds... and an introductory discussion between broadcaster Melvyn Bragg and critic and producer Martin Esslin, on 17 April 1977 in the BBC arts series The Lively Arts.

The Royal Court Theatre continued to be both a resource for desirable theatre productions of Beckett's plays that could be broadcast on television, and also a competitor as far as rights were concerned. Nevertheless, the documentary evidence is that BBC staff assumed a posture of respectful persistence in their efforts to bring Beckett's drama to the screen. Inquiries by BBC producers about rights to make television versions of Krapp's Last Tape first appear with an Existing Material Brief dated 28 August 1963 (T48/74/1), sent to the BBC Copyright department by Harry Moore of the Drama staff and resulting in a production later that year. Moore also inquired about Happy Days on 6 September 1963 and Endgame on 25 February 1964 (T48/74/1), but Beckett's antipathy to the BBC's Krapp had undermined their chances of gaining rights for adaptations, as Walford noted regretfully 
in a memo to Moore on 5 March 1964 (T48/74/1). By 16 December 1971, Tim Aspinall, producer of Thirty Minute Theatre, was trying again and sent an Existing Material Brief with an added handwritten confirmation that Michael Robson at the Curtis Brown agency had ascertained Beckett's personal agreement to a grant of rights for a BBC Krapp (T48/74/1), leading to the BBC's 1972 version, transmitted on 29 November.

Each of these adaptations was based on a Royal Court production, but television rights were always subordinate to theatre performance rights. On 15 May 1970, Rosemary Hill, Script Editor of Play of the Month, sent an Existing Material Brief to the Copyright Department on behalf of the series' producer Cedric Messina, asking about rights for Waiting for Godot (RCONT 20). The rights to Godot were not available, so only twelve days later Hill sent another form to the Copyright Department asking about the rights to Endgame instead. Later in the decade, producer Tristram Powell secured the Royal Court Theatre's production of Happy Days for recording on 5 and 6 July 1979, after clarification that the television rights were available following the stage performance (RCONT 20), and the play was screened less than a fortnight later on 18 July. Despite differences between the mooted television versions of Beckett's theatre work (such as differences in duration, type of slot in the schedule and thus differences of probable audience constituency) the producers controlling the BBC's various drama programming strands persisted in their efforts to get performances on-screen.

\section{Stepping on Other People's Toes}

However, the complexities over rights, and the number of parties involved, meant that things sometimes went wrong. There are several cases of programme-makers including extracts from Beckett's work in programmes without in advance clearing the rights to adapt the work or to broadcast an existing version. This resulted in BBC Copyright Department having to write apologetic letters to Beckett's agents, asking them to sign retrospective contracts. On 18 May 1971, the topical review programme Late Night Line-up included a feature on Beckett (RCONT 20), coinciding with the University of Reading's exhibition of archive materials. The studio guests were James Knowlson and Jack Emory, and the programme featured Sian Phillips and Jack McGowran in an extract from the BBC's television Eh Joe of 1966 and an extract from Film. The following week, on 25 May, David 
Gower of the BBC Copyright Department sent a memo to Phil Speight, producer of Late Night Line-up, complaining about the use of extracts from Eh Joe (and Film, though he was less concerned about that since it was not a BBC production). In the context of the complexities and frequent problems in clearing rights to produce Beckett's work for television, Gower was keen to make BBC staff follow the letter of the law.

The fact that Beckett's work was in several mediums, and was also adapted, sometimes caused problems over who was responsible for what. For example, requests to televise readings of his prose work, for which he was represented by his literary agent John Calder, were sent by mistake to his theatrical agents Curtis Brown instead, or vice versa. The restriction of rights to specific geographical territories led to errors over which clauses in standard contracts needed to be deleted, and letters sometimes reveal how confused and frustrated broadcasters and agency staff became. For example, on 25 January 1977 BBC copyright staff sent contracts for Beckett's new television play ...but the clouds... to the Spokesmen agency for signing, but they were the wrong type of document (RCONT 20). They were a standard form called a Tel. (2) O. S. E., but these were designed only for use when purchasing adapted material. Spokesmen sent the contracts back to the BBC on 3 February 1977, also asking BBC to delete Tryst (as Ghost Trio was still known at that time) from their file copies of previous contracts because they too were on the wrong form. Brian Turner of the BBC Copyright Department made pencil notes on the letter from Spokesmen, to clarify which plays were original and which were not. On 25 February 1977, the correct contracts were issued for the television versions of ...but the clouds... and Ghost Trio, categorising them as original works.

While these confusions were happening, on 4 February 1977 Sue Freathy at the Spokesmen agency sent a letter to B. A. Jennings of the BBC Copyright Department worrying about overseas rights (RCONT 20). Freathy had been contacted by Grove Press about the film rights to Shades in the United States, presumably because Grove might be able to exploit rights to syndicate Shades (in other words, to subcontract with broadcasters in the different regions of the USA) for showing on the PBS non-commercial channel. In fact when the contracts for Shades were signed, the clauses relating to the BBC's overseas rights in the programme were crossed through, so that they remained available for sale separately. The BBC's co-production partner, Reiner Moritz, 
gained rights for screenings of Shades in selected European countries, for example, in exchange for its financial investment (RCONT 20).

Short extracts by Beckett often featured in BBC programmes focused on his dramatic work, for example on 17 March 1966 extracts from Endgame and Waiting for Godot were included in the documentary about contemporary theatre, The Theatre Today, on $\mathrm{BBC} 2$, for a fee of $£ 3$ per minute (RCONT 18). It was stipulated that no more than five minutes of Waiting for Godot could be used. But such extracts also appeared in programmes that used Beckett's work to stand for a bleak vision of humankind that some programme-makers perceived in it. For instance, on the morning of Sunday 15 May 1966, extracts from Waiting for Godot taken from The Theatre Today, lasting two minutes, were included in a religious programme, Seeing and Believing, transmitted live from a church. On 18 December 1966, a religious programme called The New Inferno included extracts from Endgame (two minutes) and Waiting for Godot (five minutes) for which the BBC paid fees of $£ 6$ and $£ 15$ respectively.

More cheerfully, respected Beckett interpreters such as Jack McGowran or Nichol Williamson were frequently engaged at the rate of about $£ 2$ per page to read for radio or television programmes. For example, on the entertainment show Once More with Felix (starring Julie Felix) on 13 January 1968, Jack McGowran performed four minutes of Waiting for Godot for which the $\mathrm{BBC}$ cleared rights for a fee of $£ 12$ (RCONT 18). The type of BBC contract used to pay small amounts of money to performers reading a passage of Beckett's text was called a Tel. (3) Lit. Not surprisingly, BBC staff could easily become confused about whether they were contracting a performance, a reading or a dramatic production.

Looking in detail at documents surrounding the production of Beckett's work on television necessarily centres on the roles of the intermediaries and representatives who facilitated or obstructed it, and none of the documents I cite here was written by Beckett himself. However, examining how Beckett's agents and BBC staff dealt with the assignment and management of broadcasting rights sheds new light on the adaptation of his work across mediums and geographical territories. The commercial and legal contexts of copyright ownership and performing rights are significant because they determine what can be done; when, where and by whom.

\section{Notes}


1. The files consulted at the BBC Written Archives Centre comprised RCONT 18 "Samuel Beckett Copyright File 1, 1965-69," RCONT 20 "Samuel Beckett 1970-74" and T48/74/1 "Samuel Beckett Drama Writers File, 196074." Subsequent references to documents identify the type of document (letter, memo, contract, etc.), its date and the reference number of the file in which it is preserved.

2. I have been unable to determine whether such an offer from a BBC rival was actually made.

\section{Works Cited}

BBC, "Samuel Beckett Drama Writers File," BBC Written Archives Centre, Caversham, T48/74/1 (1960-74).

-, "Samuel Beckett Copyright File 1," BBC Written Archives Centre, Caversham, RCONT18 (1965-69).

-, "Samuel Beckett," BBC Written Archives Centre, Caversham, RCONT20 (1974-79).

Beckett, Samuel, Waiting for Godot (London, Faber, 1958).

-, Endgame. A Play in One Act followed by Act without Words, a Mime for One Player (London: Faber, 1958).

-, Happy Days (London: Faber, 1962).

-, Collected Shorter Plays (London: Faber, 1984).

Bignell, Jonathan, Beckett on Screen: The Television Plays (Manchester: Manchester UP, 2009).

-, "Into the Void: Beckett's Television Plays and the Idea of Broadcasting," in Beckett and Nothing, ed. Daniela Caselli (Manchester: Manchester UP, 2010), 125-42.

Cotterell, Leslie, Performance, $2^{\text {nd }}$ ed. (Eastbourne: John Offord, 1984). 